\title{
AZITHROMYCIN VERSUS ERYTHROMYCIN IN PRETERM PREMATURE RUPTURE OF MEMBRANES
}

\author{
Manal Y.M. Mohamed; Mohamed F. El-Sherbeny; Mostafa A. Elsayed and Ahmed Y. Rezk \\ Obstetrics and Gynecology Department, Faculty of Medicine, Benha University
}

ABSTRACT

The aim of this study was to compare the effectiveness of (azithromycin) compared to (erythromycin) in prolonging pregnancy in patients with Preterm Premature Rupture of Membranes (PPROM). In the present study 162 singleton pregnant women aged 18-40 years old with PPROM between 24 - 32 weeks gestation who were admitted to obstetrics and gynecology department of zagazig general hospital, within 36 hours of rupture of membranes and cervical dilation less than or equal to $4 \mathrm{~cm}$. All patients received corticosteroid in the form of (dexamethasone) $24 \mathrm{mg}$ IM injection in divided doses for 24hours to enhance lung maturity. Patients with known lethal fetal anomaly, vaginal bleeding not associated with labor , maternal or fetal indication for delivery, cervical cerclage in place, placenta previa or other known placental anomalies, use of antibiotic therapy within 5 days or allergy or other contraindications to erythromycin/azithromycin or steroid use were excluded from the study. All patients were randomly classified into two groups: Group I: included 81 patients received Erythromycin 500mg orally every 8hours for 5 days (erythromycin 500, Amirya) and Group II: included 81 patients received Azithromycin 500mg orally every 12 hours for 5 days (Zithromax 500, Pfizer). The participants are completely unaware of which group they are in and what intervention they are receiving until conclusion of the study (single blind study). There were non-significant differences between the two studied groups as regard socio-demographic data, general, local examinations, and both fetal and maternal outcomes. There was high significant difference between the costs of treatment of the two groups, azithromycin is more expensive than erythromycin but this difference has no value in relation to more side effects of erythromycin which were gastrointestinal side effects which were (33 patient in the group in erythromycin in comparison to 17 patient in the group of azithromycin). We conclude that the two drugs show similar efficacy regarding latency and both fetal and maternal outcomes.

Key Words: Foley's catheter, prostaglandin, misoprostol, second trimester missed abortion.

\section{INTRODUCTION}

$\mathrm{P}$ remature Rupture of Membranes (PROM) is a condition that occurs in pregnancy when there is rupture of membrane of the amniotic sac and chorion more than one hour before the onset of labor. PROM is prolonged when it occurs more than 18 hours before labor. PROM is preterm (PPROM) when it occurs before 37 weeks gestation and after the viability of the fetus ${ }^{(1)}$.

PPROM complicates $3 \%$ of all pregnancies and occurs in approximately 150,000 pregnancies yearly in the United States. The primary maternal risk is infection. This includes chorioamnionitis (60\%), endometritis $(2-13 \%)$, sepsis $(<1 \%)$, and maternal death (1-2 cases per 1000). Complications related to the placenta include abruption (4-12\%) and retained placenta or postpartum hemorrhage requiring uterine curettage $(12 \%)^{(2)}$.

PPROM isassociated with $30-40 \%$ of preterm deliveries and is the leading identifiable cause of preterm delivery, Eightyfive percent of neonatal morbidity and mortality is a result of prematurity ${ }^{(3)}$.
Risk factors for PROM can be maternal as a bacterial infection, include chorioamnionitis or sepsis. Smoking or anatomic defect in the structure of the amniotic sac, uterus, or cervix, preterm labor history, urinary tract infection, vaginal bleeding at any time in pregnancy, cerclage, and amniocentesis.Fetal factors include prematurity, infection, cord prolapse, malpresentation or genetic mutations ${ }^{(4)}$.

In some cases, the rupture can spontaneously heal, but in most cases of PROM, labor begins within 48 hours. When this occurs, it is necessary that the mother receives treatment to avoid possible infection in the newborn ${ }^{(5)}$.

Mercer et al. ${ }^{(6)}$ demonstrated the advantages and disadvantages of using antibiotics and the choice of antibiotics. In most studies, use of antibiotics has been associated with prolongation of pregnancy and reduction in infant and maternal morbidity.

The goal of this study is to compare the effectiveness of (azithromycin) compared to (erythromycin) in prolonging pregnancy in 
patients with Preterm Premature Rupture of Membranes (PPROM).

\section{PATIENTS AND METHODS}

The study is a prospective randomized controlled study it was conducted in zagazig general hospital.

\section{Inclusion criteria:}

162 pregnant women between the gestational age of 24 weeks and32weeks had definite rupture of membranes is documented by evident gush of fluid from external OS during speculum examination the patients were divided randomly into two groups

Group I included 81 patients received Erythromycin 500mg orally every 8 hours for 5 days (Erythromycin 500, Amirya, Egypt).

Group II included 81 patients received Azithromycin 500mg orally every 12 hours for 5 days (Zithromax500, Pfizer, USA).

In this study the participants are completely unaware of which group they are in and what intervention they are receiving until conclusion of the study (single blinded study).

\section{Exclusion Criteria:}

- Known lethal fetal anomaly.

- Vaginal bleeding not associated with labor.

- Maternal or fetal indication for delivery.

- Cervical cerclage in place.

- Placenta previa or other known placental anomalies.

- Use of antibiotic therapy within 5 days.

- Allergy or other contraindications to erythromycin /azithromycin or steroid use.

\section{Methods:}

- The patient signed an informed consent before being included in the study.

- Full history taken including onset, amount and color of the fluid leaked was taken.

- General and abdominal examination was done including maternal vital signs.

- Local examination was done in the lithotomy position /sterile Bivalve vaginal speculum was introduced under complete aseptic condition.

- Cervical dilatation was noted. The patient asked to strain to document gush of fluid from external cervical os.

- Laboratory investigation was done in the form of total leucocyte count and CRP titer.
- The patient had an ultrasound examination to detect the amount of amniotic fluid, AFI is measured.

\section{Outcome measures: \\ Primary measures:}

Primary outcome measure is the duration of latency in the two groups (defined as the time of gap between onset of rupture of membrane and delivery.

\section{Secondary measures:}

Secondary outcomes of neonatal death, neonatal respiratory distress requiring oxygen supplementation reviewed. In addition, cost of drugs and side effects profiles between the two will be assessed in post treatment patient survey.

\section{Statistical analysis:}

All data were analyzed using SPSS 15.0 for windows (SPSS Inc., Chicago, IL, USA) \&Med Calc 13 for windows (MedCalc Software bvba). Continuous data are expressed as the mean \pm SD \& median (range), and the categorical data are expressed as a number (percentage). Continuous data were checked for normality by using Shapiro-Wilk test. Mann-Whitney U (MW) test was used to compare two groups of nonnormally distributed data. Categorical data were compared using the Chi-square $\left(\chi^{2}\right)$ test. All tests were two sided.p $<0.05$ was considered statistically significant $(\mathrm{S}), \mathrm{p}<$ 0.01 was considered highly statistically significant (HS), and $\mathrm{p}>0.05$ was considered non statistically significant (NS).

\section{RESULTS}

Table (1) shows comparisons between the two groups as regard age rgestational age at time of PROM sparity, number of cesarean section.There is non-significant difference between age (in years), gestational age (in weeks) 'parity and number of cesarean section between the two groups.

Table (2) shows comparisons between the two groups as regard general examinations including maternal temperature and heart rate. There is non-significant difference between temperature and heart rate between the two groups.

Table (3) shows comparison between the two groups as regard local examination .There is non-significant difference between local examinations of the two groups. 
Table (4) shows comparison between the two groups as regard Laboratory and radiological examinations. There is nonsignificant difference between Laboratory examinations including $\mathrm{C}$-reactive protein (CRP) and total leucocyte count (TLC) and radiological examinations including amniotic fluid index (AFI) and fetal heart rate (FHR) of the two groups.

Table (5) shows comparison between the two groups as regard maternal outcome including latency, mode of delivery, chorioamnionitis and post-partum hemorrhage. There is non-significant difference between the two groups.

Table (6) shows comparison between the two groups as regard fetal outcomes including gestational age at birth (weeks), birth weight (grams) and Apgar score at time of delivery, respiratory distress, neonatal sepsis and neonatal death. There is nonsignificant difference between the two groups as regard fetal outcomes

Table (7) shows comparison between the two groups as regard side effects which were in the form of gastrointestinal symptoms including nausea, vomiting and diarrhea there is statistically significant difference between the two groups as regard side effects of administrated drugs.

Table (8) shows comparison the cost of treatment of the two groups. There is high significant difference between the two groups as regard the cost of administrated drugs.

Table (1): Comparison between variants of socio-demographic data of the 2 groups:

\begin{tabular}{|c|c|c|c|c|}
\hline Variable & $\begin{array}{l}\text { Erythromycin } \\
\text { group } \\
(\mathbf{n}=\mathbf{8 1})\end{array}$ & $\begin{array}{l}\text { Azithromycin } \\
\text { group } \\
(\mathbf{n}=\mathbf{8 1})\end{array}$ & $\mathbf{T}$ & $\mathbf{P}$ \\
\hline $\begin{array}{l}\text { Age (Years): } \\
\text { Mean } \pm S D \\
\text { Range }\end{array}$ & $\begin{array}{c}29.79 \pm 5.54 \\
18-40 \\
\end{array}$ & $\begin{array}{c}29.70 \pm 4.89 \\
18-37 \\
\end{array}$ & 1.76 & $\begin{array}{l}0.15 \\
\text { N.S }\end{array}$ \\
\hline $\begin{array}{l}\text { Gestational Age (weeks) at time of } \\
\text { PROM: } \\
\text { Mean } \pm S D \\
\text { Range } \\
\end{array}$ & $\begin{array}{c}29.68 \pm 1.83 \\
26-32\end{array}$ & $\begin{array}{c}29.73 \pm 1.97 \\
24-32\end{array}$ & 0.17 & $\begin{array}{l}0.87 \\
\text { N.S }\end{array}$ \\
\hline $\begin{array}{l}\text { Parity : } \\
\text { Mean } \pm S D \\
\text { Range }\end{array}$ & $\begin{array}{c}3.1 \pm 0.8 \\
0-5 \\
\end{array}$ & $\begin{array}{c}2.3 \pm 0.9 \\
0-5 \\
\end{array}$ & 1.174 & $\begin{array}{c}0.246 \\
\text { N.S } \\
\end{array}$ \\
\hline $\begin{array}{l}\text { No of CS: } \\
\text { Mean } \pm S D \\
\text { Range }\end{array}$ & $\begin{array}{c}1.2 \pm 5 \\
0-2\end{array}$ & $\begin{array}{c}1.1 \pm 6 \\
0-3\end{array}$ & 1.313 & $\begin{array}{c}0.196 \\
\text { N.S }\end{array}$ \\
\hline
\end{tabular}

Table (2): Comparison between the general examinations of the two groups:

$\begin{array}{lllll}\text { Variable } & \begin{array}{l}\text { Erythromycin } \\ \text { group }(\mathbf{n}=\mathbf{8 1})\end{array} & \begin{array}{l}\text { Azithromycin } \\ \text { group }(\mathbf{n}=\mathbf{8 1})\end{array} & \mathbf{T} & \mathbf{P}\end{array}$

\begin{tabular}{|c|c|c|c|c|}
\hline $\begin{array}{l}\text { Temperature }\left({ }^{\circ} \mathbf{C}\right): \\
\text { Mean } \pm S D \\
\text { Range }\end{array}$ & $\begin{array}{c}37.09 \pm 1.33 \\
36.5-39\end{array}$ & $\begin{array}{c}36.93 \pm 1.14 \\
36-38\end{array}$ & 1.17 & $\begin{array}{l}0.25 \\
\text { N.S }\end{array}$ \\
\hline $\begin{array}{l}\text { Heart Rate } \\
\text { (beat/minute): } \\
\text { Mean } \pm S D \\
\text { Range }\end{array}$ & $\begin{array}{c}81.48 \pm 7.73 \\
70-110\end{array}$ & $\begin{array}{c}80.19 \pm 8.24 \\
70-110\end{array}$ & 1.03 & $\begin{array}{l}0.30 \\
\text { N.S }\end{array}$ \\
\hline
\end{tabular}


Table (3): Comparison between the local examinations of the two groups:

\begin{tabular}{|c|c|c|c|c|c|c|c|}
\hline \multirow{2}{*}{\multicolumn{2}{|c|}{ Cervix examination: }} & \multicolumn{2}{|c|}{$\begin{array}{l}\text { Erythromycin } \\
\text { group }(\mathbf{n}=\mathbf{8 1})\end{array}$} & \multicolumn{2}{|c|}{$\begin{array}{l}\text { Azithromycin } \\
\text { group }(\mathbf{n}=\mathbf{8 1})\end{array}$} & \multirow[t]{2}{*}{$\chi^{2}$} & \multirow[t]{2}{*}{$\mathbf{P}$} \\
\hline & & $\mathbf{N}$ & $\%$ & $\mathbf{N}$ & $\%$ & & \\
\hline \multicolumn{2}{|r|}{ Closed } & 73 & 90.1 & 74 & 91.4 & 0.07 & $\begin{array}{l}0.79 \\
\text { N.S }\end{array}$ \\
\hline Open & $\begin{array}{l}\text { Size: } \\
\text { Mean } \pm S D \\
\text { Range }\end{array}$ & $\begin{array}{c}8 \\
2.38 \pm 1.06 \\
1-4\end{array}$ & 9.9 & $\begin{array}{c}7 \\
2.42 \pm 0.98 \\
1-4\end{array}$ & 8.6 & 0.10 & $\begin{array}{l}0.92 \\
\text { N.S }\end{array}$ \\
\hline
\end{tabular}

Table (4): Comparison between the Laboratory and radiological examinations of the two groups

\begin{tabular}{|c|c|c|c|c|}
\hline Variable & $\begin{array}{l}\text { Erythromycin } \\
\text { group }(n=81)\end{array}$ & $\begin{array}{l}\text { Azithromycin group } \\
(\mathbf{n}=\mathbf{8 1})\end{array}$ & & $\overline{\mathbf{P}}$ \\
\hline $\begin{array}{l}\text { CRP(mg/ml): } \\
\text { Mean } \pm S D \\
\text { Range }\end{array}$ & $\begin{array}{c}8.56 \pm 4.86 \\
2-30\end{array}$ & $\begin{array}{c}7.60 \pm 4.71 \\
2-33\end{array}$ & 1.26 & $\begin{array}{l}0.21 \\
\text { N.S }\end{array}$ \\
\hline 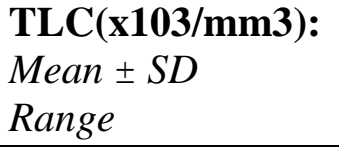 & $\begin{array}{c}8.65 \pm 3.26 \\
4-20\end{array}$ & $\begin{array}{c}9.28 \pm 3.35 \\
5-25\end{array}$ & 1.21 & $\begin{array}{l}\cdot, r T \\
\text { N.S }\end{array}$ \\
\hline $\begin{array}{l}\text { AFI }(\mathbf{c m}): \\
\text { Mean } \pm S D \\
\text { Range }\end{array}$ & $\begin{array}{c}5.64 \pm 2.31 \\
1-11\end{array}$ & $\begin{array}{c}5.23 \pm 1.83 \\
1-10\end{array}$ & 0.70 & $\begin{array}{l}0.48 \\
\text { N.S }\end{array}$ \\
\hline $\begin{array}{l}\mathbf{F H R}(\mathbf{b} / \mathbf{m}): \\
\text { Mean } \pm S D \\
\text { Range }\end{array}$ & $\begin{array}{c}142.33 \pm 13.14 \\
120-185\end{array}$ & $\begin{array}{c}140.37 \pm 11.89 \\
120-180\end{array}$ & 0.99 & $\begin{array}{l}0.32 \\
\text { N.S }\end{array}$ \\
\hline
\end{tabular}

Table (5): comparison between the two groups as regard maternal outcomes:

\begin{tabular}{|c|c|c|c|c|c|c|}
\hline \multirow{3}{*}{$\begin{array}{l}\text { Latency: (Days) } \\
\text { Mean } \pm S D \\
\text { Range }\end{array}$} & \multicolumn{2}{|c|}{$\begin{array}{l}\text { Erythromycin } \\
\text { group }(\mathbf{n}=81)\end{array}$} & \multicolumn{2}{|c|}{$\begin{array}{l}\text { Azithromycin group } \\
(\mathbf{n}=\mathbf{8 1})\end{array}$} & $\mathbf{T}$ & $\mathbf{P}$ \\
\hline & \multicolumn{2}{|c|}{$\begin{array}{c}15.12 \pm 8.40 \\
1-35\end{array}$} & \multicolumn{2}{|c|}{$\begin{array}{c}16.85 \pm 6.43 \\
5-28\end{array}$} & 1.47 & $\begin{array}{l}0.14 \\
\text { N.S }\end{array}$ \\
\hline & $\mathbf{N}$ & $\%$ & $\mathbf{N}$ & $\%$ & $\chi^{2}$ & $\mathbf{P}$ \\
\hline $\begin{array}{l}\text { Mode of delivery: } \\
N V \\
C S\end{array}$ & $\begin{array}{l}52 \\
29\end{array}$ & $\begin{array}{l}64.2 \\
35.8\end{array}$ & $\begin{array}{l}55 \\
26\end{array}$ & $\begin{array}{l}67.9 \\
32.1\end{array}$ & 0.25 & $\begin{array}{l}0.62 \\
\text { N.S }\end{array}$ \\
\hline $\begin{array}{l}\text { Chorioamnionitis: } \\
\text { No } \\
\text { Yes }\end{array}$ & $\begin{array}{c}76 \\
5\end{array}$ & $\begin{array}{c}93.8 \\
6.2\end{array}$ & $\begin{array}{c}77 \\
4\end{array}$ & $\begin{array}{c}95.1 \\
4.9\end{array}$ & 0.12 & $\begin{array}{l}0.73 \\
\text { N.S }\end{array}$ \\
\hline $\begin{array}{l}\text { Post-partum } \\
\text { hemorrhage: } \\
\text { No } \\
\text { Yes }\end{array}$ & $\begin{array}{c}78 \\
3\end{array}$ & $\begin{array}{c}96.3 \\
3.7\end{array}$ & $\begin{array}{c}76 \\
5\end{array}$ & $\begin{array}{c}93.8 \\
6.2\end{array}$ & 0.53 & $\begin{array}{l}0.47 \\
\text { N.S }\end{array}$ \\
\hline
\end{tabular}


Table (6): Comparison between the two groups as regard fetal outcomes of the two groups:

\begin{tabular}{|c|c|c|c|c|c|c|}
\hline Variable & \multicolumn{2}{|c|}{$\begin{array}{l}\text { Erythromycin } \\
\text { group } \\
(n=81)\end{array}$} & \multicolumn{2}{|c|}{$\begin{array}{c}\text { Azithromycin } \\
\text { group } \\
(n=81)\end{array}$} & $\mathbf{T}$ & $\mathbf{P}$ \\
\hline $\begin{array}{l}\text { Gestational age at } \\
\text { birth:(week) } \\
\text { Mean } \pm S D \\
\text { Range } \\
\end{array}$ & \multicolumn{2}{|c|}{$\begin{array}{c}31.96 \pm 2.25 \\
26-34\end{array}$} & \multicolumn{2}{|c|}{$\begin{array}{c}32.16 \pm 2.24 \\
26-34\end{array}$} & 0.55 & $\begin{array}{l}0.59 \\
\text { N.S }\end{array}$ \\
\hline $\begin{array}{l}\text { Birth wt:(gm) } \\
\text { Mean } \pm S D \\
\text { Range }\end{array}$ & \multicolumn{2}{|c|}{$\begin{array}{c}1081.2 \pm 464.4 \\
750-2400\end{array}$} & \multicolumn{2}{|c|}{$\begin{array}{c}1830.9 \pm 448.9 \\
700-2300\end{array}$} & 0.41 & $\begin{array}{l}0.68 \\
\text { N.S }\end{array}$ \\
\hline \multirow[t]{2}{*}{$\begin{array}{l}\text { Apgar score: } \\
\text { Mean } \pm S D \\
\text { Range } \\
\end{array}$} & \multicolumn{2}{|c|}{$\begin{array}{c}7.09 \pm 1.79 \\
2-9 \\
\end{array}$} & \multicolumn{2}{|c|}{$\begin{array}{c}7.11 \pm 1.79 \\
2-9 \\
\end{array}$} & 0.04 & $\begin{array}{l}0.97 \\
\text { N.S } \\
\end{array}$ \\
\hline & $\mathbf{N}$ & $\%$ & $\mathbf{N}$ & $\%$ & $\chi^{2}$ & $\mathbf{P}$ \\
\hline \multicolumn{6}{|l|}{$\begin{array}{l}\text { Neonatal respiratory } \\
\text { distress: }\end{array}$} & $\begin{array}{l}0.60 \\
\text { N.S }\end{array}$ \\
\hline $\begin{array}{l}\text { Neonatal sepsis: } \\
\text { No } \\
\text { Yes }\end{array}$ & $\begin{array}{l}69 \\
12\end{array}$ & $\begin{array}{l}85.2 \\
14.8\end{array}$ & $\begin{array}{c}72 \\
9\end{array}$ & $\begin{array}{l}88.9 \\
11.1\end{array}$ & 0.49 & $\begin{array}{l}0.48 \\
\text { N.S }\end{array}$ \\
\hline $\begin{array}{l}\text { Neonatal death: } \\
\mathrm{No} \\
\mathrm{Yes}\end{array}$ & $\begin{array}{c}80 \\
1\end{array}$ & $\begin{array}{c}98.7 \\
1.3\end{array}$ & $\begin{array}{c}79 \\
2\end{array}$ & $\begin{array}{c}97.5 \\
2.5\end{array}$ & 0.34 & $\begin{array}{l}0.56 \\
\text { N.S }\end{array}$ \\
\hline
\end{tabular}

Table (7): Comparison between Drug side effects in the two groups:

\begin{tabular}{|c|c|c|c|c|c|c|}
\hline \multirow{2}{*}{ Variable } & \multicolumn{2}{|c|}{$\begin{array}{c}\text { Erythromycin } \\
\text { group } \\
(n=81) \\
\end{array}$} & \multicolumn{2}{|c|}{$\begin{array}{c}\text { Azithromycin } \\
\text { group } \\
(n=81) \\
\end{array}$} & \multirow{2}{*}{$\chi^{2}$} & \multirow{2}{*}{$\mathbf{P}$} \\
\hline & $\mathbf{N}$ & $\%$ & $\mathbf{N}$ & $\%$ & & \\
\hline $\begin{array}{l}\text { Nausea: } \\
\text { No } \\
Y e s\end{array}$ & $\begin{array}{l}62 \\
19\end{array}$ & $\begin{array}{l}76.5 \\
23.5\end{array}$ & $\begin{array}{c}72 \\
9\end{array}$ & $\begin{array}{l}88.9 \\
11.1\end{array}$ & 4.32 & $0.04 *$ \\
\hline $\begin{array}{l}\text { Vomiting: } \\
\text { No } \\
\text { Yes } \\
\end{array}$ & $\begin{array}{l}66 \\
15\end{array}$ & $\begin{array}{l}81.5 \\
18.5\end{array}$ & $\begin{array}{c}75 \\
6 \\
\end{array}$ & $\begin{array}{c}92.6 \\
7.4\end{array}$ & 4.43 & 0.03* \\
\hline $\begin{array}{l}\text { Diarrhea: } \\
\text { No } \\
\text { Yes }\end{array}$ & $\begin{array}{c}72 \\
9\end{array}$ & $\begin{array}{l}88.9 \\
11.1\end{array}$ & $\begin{array}{c}79 \\
2\end{array}$ & $\begin{array}{c}97.5 \\
2.5\end{array}$ & 4.78 & $0.02 *$ \\
\hline
\end{tabular}


Table (8): Comparison between the costs of treatment of the two groups:

\begin{tabular}{ccc} 
Variable & $\begin{array}{c}\text { Erythromycin } \\
\text { group } \\
(\boldsymbol{n = 8 1})\end{array}$ & $\begin{array}{c}\text { Azithromycin group } \\
(\boldsymbol{n}=\mathbf{8 1})\end{array}$ \\
\hline Dose: & $1 \times 3 \times 5$ & $2 \times 2 \times 5$ \\
Total & 15 tabs. & $20 \mathrm{caps}$. \\
Concentration: & $500 \mathrm{mg}$ & $250 \mathrm{mg}$ \\
Net Cost : $(\mathbf{L E})$ & 13 & 261 \\
\hline
\end{tabular}

\section{DISCUSSION}

Preterm PROM complicates $2 \%$ to $20 \%$ of all deliveries and is associated with $18 \%$ to $20 \%$ of perinatal deaths. Management options include admission to hospital, amniocentesis to exclude intra-amniotic infection, and administration of antenatal corticosteroids and broad-spectrum antibiotics, if indicated ${ }^{(7)}$.

Kenyon et al. ${ }^{(8)}$ recommended broadspectrum coverage in latency antibiotic regimens. Many antibiotic regimens have been evaluated in both a prospective and retrospective fashion and no treatment regimen has been found superior; all regimens are superior to placebo.

The study was conducted in obstetrics and gynecology department of Zagazig general hospital from whom they receive corticosteroid in the form of (dexamethasone) $24 \mathrm{mg}$ IM injection in divided doses for 24hours to enhance lung maturity.

In this study, there were non-significant differences between the two studied groups as regard gestational age, parity, number of previous cesarean sections, temperature, heart rate, total leucocytic count, C-reactive protein concentration, fetal heart rate, amniotic fluid index, mode of delivery and cervical examination.

In this study; the group of patients who received erythromycin has latency period 135 days in comparison to 2-28 days for the group of patients who received azithromycin. This result is more or less similar that reported by Mercer and Arheart ${ }^{(9)}$, the latency period ranged from 1.4 to 12.0 days.

Pierson et al. ${ }^{(10)}$ evaluated whether the use of ampicillin and azithromycin led to a similar latency period compared with the recommended regimen of ampicillin and erythromycin and determined whether the substitution of azithromycin for erythromycin affected rates of other maternal and neonatal outcomes. They concluded that among women with preterm premature rupture of membranes between 24 and 34 completed weeks of gestation, substitution of azithromycin for erythromycin in the recommended antibiotic regimen did not affect latency or any other measured maternal or fetal outcomes.

We found non-significant differences between the two studied groups regard maternal outcome measures including chorioamnionitis and postpartum hemorrhage and fetal outcome measures including birth weight, Apgar score, neonatal respiratory distress syndrome, neonatal sepsis and neonatal death.

Kenyon et al. ${ }^{(11)}$ assessed the effects of administering antibiotics to women with preterm rupture of membranes on fetal and neonatal morbidity and mortality, maternal infectious morbidity and mortality, and longterm childhood development. They concluded that antibiotic administration following PROM is associated with a delay in delivery and a reduction in some markers of neonatal morbidity (prolongation of pregnancy, infection and less abnormal cerebral ultrasound before discharge from hospital) and yet in the longer term follow up at seven years of age showed no evidence of either benefit or harm. Benefits in some short-term outcomes should be balanced against a lack of evidence of benefit for others, including perinatal mortality, and longer term outcomes. If antibiotics are prescribed, it is unclear which would be the antibiotic of choice.

We found statistically significant difference between the two studied groups as regard gastrointestinal side effects as regards nausea (19:9), vomiting (15:6) and diarrhea 
(9:2) respectively in erythromycin group compared to azithromycin group.

Pitsouni et al. ${ }^{(\mathbf{1 2})}$ investigated the efficacy and safety of azithromycin in comparison with erythromycin and/or amoxicillin for the treatment of $C$. trachomatis infection in pregnant women. The study included 587 pregnant women with microbiologically documented $C$. trachomatis infection. There was no difference between azithromycin and erythromycin regarding treatment success in intention-to-treat patients or in clinically evaluated patients. Furthermore, azithromycin was associated with fewer gastrointestinal adverse events, fewer total adverse events, a smaller proportion of patients who withdrew from the study and better compliance than erythromycin. They concluded that azithromycin is as effective but safer for the treatment of $C$. trachomatis infection in pregnant women.

American College of Obstetricians and Gynecologists ${ }^{(13)}$ discussed the use of ampicillin and erythromycin as the recommended regimen for PROM. As a result of concerns about the maternal side effects of erythromycin and the ease of administration of azithromycin, many healthcare providers have changed their preferred antibiotic regimen to the combination of ampicillin and azithromycin.

There is high significant difference between the cost of treatment of the two groups, azithromycin is more expensive than erythromycin but this difference has no value in relation to more side effects of erythromycin which were gastrointestinal side effects including nausea, vomiting and diarrhea which were (33 patients in the group of erythromycin in comparison to 17 in the group of azithromycin).

\section{CONCLUSION}

- The two drugs show similar efficacy regarding latency and both fetal and maternal outcomes.

- There were more gastrointestinal side effects in the erythromycin group in comparison to azithromycin group.
- The cost of treatment in group of azithromycin is more expensive than erythromycin group.

\section{REFERENCES}

1- Deering SH, Patel N, Spong CY, et al.; (2007): "Fetal growth after preterm premature rupture of membranes: is it related to amniotic fluid volume?". J. Matern. Fetal. Neonatal. Med. 20 (5): 397-400.

2- Mercer BM (2004): Preterm rupture of the membranes: diagnosis and management. ClinPerinatol; 31:765-82.

3- Aagaard-Tillery KM, Nuthalapaty FS, Ramsey PS, et al.; (2005): Preterm premature rupture of membranes: perspectives surrounding controversies in management. Am J Perinatol; 22(6):287-97.

4- Santos Leal E, Odent MR, Vidart Aragon JA, et al.;(2006): Premature Rupture of Membranes and Madrid Terrorist Attack. Birth 33 (4): 341.

5- Simhan HN and Canavan TP (2005): Preterm premature rupture of membranes: diagnosis, evaluation and management strategies. BJOG; 112 Suppl 1:32-7.

6- Mercer BM, Miodovnik $M$ and Thurnau GR .(1997): Antibiotic therapy for reduction of infant morbidity after preterm premature rupture of the membranes. A randomized controlled trial. National Institute of Child Health and Human Development MaternalFetal Medicine Units Network. JAMA. Sep 24 1997;278(12):989-95.

7- Caughey AB, Robinsons JN and Norwitz ER (2008): Contemporary diagnosis and management of preterm premature? rupture of membranes. Rev ObstetGynecol 1(1) 111-22.

8- Kenyon S, Boulvain $M$ and Neilson $J$ (2013): Antibiotics for preterm rupture of membranes. The Cochrane Database of Systematic Reviews; Issue 12. Art. No.: CD001058.

9- Mercer BM and Arheart KL (1996): Antibiotic therapy for preterm premature rupture of the membranes. SeminPerinatol; 20: 426-38.

10- Pierson RC, Gordon SS and Haas DM (2014): A retrospective comparison of antibiotic regimens for preterm premature rupture of membranes. ObstetGynecol; 124: 515-9.

11- Kenyon S, Boulvain $M$ and Neilson $J$ (2010): Antibiotics for preterm rupture of membranes. Cochrane Database of Systematic Reviews; Issue 8. Art. No.: CD001058.

12- Pitsouni E, Iavazzo $C$, Athanasiou S, Falagas $\quad \mathbf{M} \quad \mathbf{E}(\mathbf{2 0 0 7 )}:$ Single-dose 
azithromycin versus erythromycin or amoxicillin for Chlamydia trachomatis infection during pregnancy: a meta-analysis of randomised controlled trials. International Journal of Antimicrobial Agents; 30(3): 213221
13- American College of Obstetricians and Gynecologists (2013): Premature rupture of membranes. Practice Bulletin No. 139. Obstet Gynecol; 122:918-30. 